\title{
BUDGET PROVISIONS IN COMMISSION-GOVERNED CITIES
}

By L. G. Powers,

Chief Statistician, Bureau of the Census, Washington, D. C.

The commission form of government is being advocated at the present time in the United States by the two classes of people who are as widely separated in their motives for urging its introduction as the poles of the earth. The members of one of these classes favor the Galveston or Des Moines plan, because they believe it will afford the masses a better knowledge of and control over municipal affairs, and that there can be no progress or improvement of city government without the active participation of the people as a whole in such government. The second class advocate the scheme from an opposite motive. Its members despair of popular government and favor a benevolent despotism, which they conceive the commission plan of government to be. But strange as it may seem, both classes urge the adoption of the commission plan because it secures a greater publicity of affairs, and through that publicity, more economical and efficient administration.

But publicity, or providing information for the use of the public, cannot be a factor of continuing good government, unless the popular judgment based on that information and the popular control which results therefrom are beneficial. In urging the added publicity that follows the introduction of the commission form of government as a reason for the adoption of that form, the advocates of a benevolent system of municipal despotism in reality discard their theoretical position and recognize that democratic government based upon popular intelligence is the only form that can be depended upon to be efficient and economical. In other words, they tacitly admit that more democracy is the cure for the ills of democracy as we now find them in city governments.

The writer will not here discuss the question of how the various cities introducing the commission form of government have been given greater publicity of affairs as the result of the adoption of the

(798) 
new organization. A hasty, and therefore more or less imperfect study in this field, discloses the fact that the added publicity and the increased popular interest which have been awakened, thereby resulting in better government, have had different contributing factors in the cities so far introducing the new form. Some of these factors are local and transient in their nature, and cannot reasonably be expected to be continuous in their operation, and hence assist in securing economy and efficiency of government for any great numbers of years. Only one of them can be made a continuous and potent agent of governmental publicity, and that is the budget, or annual appropriation act. It is for this reason that commissions which, by the present popular wave, are being intrusted with a large place in the government of our cities, if desirous of advancing efficient and economical, as well as wise administration, will find a scientifically arranged budget supported by proper accounts, reports and supplementary statements, the most effective agent for keeping in touch with the people, and bringing them to the support of good plans for the administration of city finances.

But how shall a budget be so arranged as fittingly to be called "scientific?" Or what shall be its provisions that it may, by the publicity that it affords, be a continuing factor of good, efficient, and economical government.

In present city governments by councils and executive officers, budgets too frequently are patterned upon the financial statements of private corporations, which are so arranged as to conceal from the stockholders and from all but a selected few, the real results of financial transactions and the-real condition of business affairs. The private corporations referred to use as one of the agents of this concealment what accountants call "secret reserves," or assets covered up under designations that make them appear as negations of property, or even as liabilities. Such statements in private corporate accounting are nearly always made for the purpose of enabling those manipulating accounts and statements to secure a gain for themselves at the expense of the great body of the stockholders, and whether made with such intent or not, they always work to that end.

Governmental budgets framed along the lines of private corporate accounts and statements with secret reserves are statements of proposed expenditures and of methods of providing money for 
meeting the same whose significance a limited few in the legislative bodies fully understand, but which is not apparent to the average person, who will give to'it a meaning quite different from its actual significance. Such budgets may be employed by city commissioners; but if so used to any great extent, will inevitably lead to graft, inefficiency, and wastefulness; and that form is doomed. The correlative of private secret reserves is usually found in the incompleteness of city budgets and their lack of systematic arrangement, and thus of lucid or intelligent presentation. These defects will be considered in the order here mentioned.

To be an instrument of complete publicity concerning proposed financial transactions, municipal budgets must have the same characteristics as the budgets of the British National Government, from which we derive the word "budget" with the significance which it now has in municipal affairs. They must be complete statements of the proposed expenditures for the ensuing year, with financial proposals founded thereon, including statements of proposed tax rates and moneys to be obtained by the use of governmental credit.

A complete budget, such as has been here described, whether framed along intelligible lines for details, or otherwise, shows the relation of revenues to expenditures and the net effect of the proposed financial transactions of the year upon the amount of municipal indebtedness. It discloses whether the expenditures will exceed or fall short of the revenues, and thus whether the expenditures must be met in part by the issue of bonds or other forms of credit, or whether the end of the year will find the city's indebtedness decreased, or its available resources increased. This information is needed by the commission under that form of government, or its members cannot have the basis for any broad or comprehensive plans for the administration of city finance, without which neither they nor any other set of government officials can administer municipal affairs either intelligently or well. Further, without giving the citizens of the municipality this information in the budget, or otherwise, there can be no basis for an intelligent popular judgment concerning the wisdom of the general plans for the community. The city may have a benevolent or well-meaning despotism, but such well-meaning, or good intentions, in governmental affairs without adequate knowledge, are usually the paving stones of an inferno of bad and inefficient administration that will surely be let 
loose on the community not governed by intelligence or directed by well-considered financial plans. The city will drift, under such circumstances, without any well-directed popular judgment concerning its affairs, and there is no charm in the name "Commission" that will save the community from lack of knowledge, for which the people perish to-day as in the days of Ancient Writ.

The incompleteness of American municipal budgets usually results from preparing those documents in sections at different times. Cities with the most defective financial proposals of this character are those which introduce and pass revenue appropriations, or appropriations for departmental expenses and outlays to be met from revenue, in a number of sections at different times. Cities with the least defective budgets in this respect are those which merely separate appropriations from bond issues and expenditures to be met from special assessments from other appropriations. The variation between these classes of cities is one of degree but not of character.

In making appropriations, expenditures and the resources for meeting them should be considered as parts of the same whole; and no budget of municipal expenditures should be considered complete unless it is accompanied with two proposals setting forth how the money is to be raised for meeting the proposed expenditures if authorized. The necessity for this completeness of budget can best be seen in one of its aspects when it is considered in its relation to the city planning movement. That movement has demonstrated the desirability of having comprehensive plans for the development of the commercial possibilities of cities, the location and arrangement of public buildings in accordance with designs that foster beauty and harmony of architectural arrangement, the making of park provisions for the growing population, the designing of good streets, boulevards and sewer systems, and securing adequate systems of water supply. These plans, to attain their full realization without undue burdens of debt or taxation, and without long delays and their resulting added costs, must secure the co-operation of city officials, the membership of commercial bodies and of all other civic organizations. So far, one of the desirable results of the adoption of the commission form of government has been the stimulation of the city planning movement in the cities adopting the same. But wise city planning cannot be adopted without a long look ahead, and 
schemes for a number of years which will set forth for each of those years the relation of expenditures to the means adopted for providing the money for meeting the expenditures, and the presentation of annual budgets in accordance with the provisions of the city plan.

Further, any way of treating expenditures of the budget and the moneys for meeting them, other than the one here outlined, under any form of government, whether commission or otherwise, leads inevitably to departmental and personal favoritism. It leads to raising money for certain classes of expenditures in one section of the city by one method, and in another part of the city by a different one. In one section the costs of a certain class of public improvements will be financed by special assessments, while in another the same costs will be borne by general taxes or from the proceeds of bond issues. These are evils which may be found in all cities with the old council form of government and with incomplete budget statements. Similar evils must inevitably result from the same method of preparing budgets in commission-governed cities; hence, I repeat, one, and the most essential, provision of budgets in commission-governed cities must be their completeness as statements of all proposed expenditures, and of the sources from which it is planned to secure the wherewithal for meeting those expenditures and the wisdom or folly of all proposed financial measures and their relation to popular welfare now and in the future.

But completeness is not the only provision that should and must be embodied in the budgets of commission-governed cities to make them effective for good government. The budget must be arranged in a systematic and orderly manner, so that it becomes a lucid and intelligent statement of all the proposals, whose significance any one at all familiar with municipal affairs can easily grasp. The classification of expenditures should be along functional lines with items in groups and sub-groups, and arranged under heads and titles with which every one is more or less familiar. The budget is no place for exhibiting the attainments of the academic school man. The classification must be arranged to set forth the relation of the proposed expenditures to the activities of the city as the people know those activities. It must give group and sub-group totals and subordinate details for all such functional activities as those for the police department, fire department, health department, schools, 
charities, hospitals, highways, sewers, sanitation, etc., with which the people are all familiar.

Without an analytical presentation of proposed expenditures arranged along functional lines as above described, city budgets in the past have often been the plaything of city bosses to fool and throw dust in the people's eyes. With an analytical presentation along scientifically classified lines, that financial statement may readily be made a most potent factor for guaranteeing an economical, efficient, and altogether satisfactory administration of municipal affairs.

Such a classification and presentation of proposed expenditures in the budget, to accomplish the results last stated, should be accompanied with an exhibit of the expenditures and receipts, or revenues and receipt from increasing debt for the preceding year. Students of municipal administration began the agitation for uniform accounts and reports quite a number of years ago. Such accounts and reports, though accomplishing much as aids to good government, have failed of realizing all the good results anticipated, and for the following reasons:

They are always statements of past transactions. If by chance they are the records of waste, inefficiency, or graft in administration, unless such waste, inefficiency and graft are striking, or even shocking in their magnitude, the exhibit of the same does not excite a great measure of poptlar interest. The reason for this fact is found in the popular speech when such exhibits are called a "story of dead horses." It is a closed chapter in the popular mind. The public are unwilling to waste a great deal of time around the stable door after the horse has been stolen. Now, while this is true, the same exhibit of governmental expenses presented as an accompaniment of a comparable exhibit of proposed transactions that can be prevented by a popular protest or aided by a popular advocacy will at once attract attention, as has been repeatedly illustrated by the results of the budget exhibit in New York and other cities in recent years.

The analytical exhibit of proposed expenditures and proposals for providing the resources for meeting the same is to be commended, not alone as an instrument for awakening popular interest to prevent graft, wastefulness, and inefficiency that are fostered by improper appropriations; they are more to be commended by reason of their 
intimate relation to the wise and necessary increase in municipal expenditures which is called for everywhere in recent years by the fact that cities are finding out how, by enlarged public expenditures, their governments can be made to assist the people to added health, comfort, strength, and pleasure that otherwise is unattainable for them.

The analytical budget, supported by analytical reports of past expenditures, provides the basis for popular judgment concerning the relative merits or claims of the several branches of the departmental service for increased appropriations from public money; and such budgets under these circumstances tend to prevent favoritism for any one or more branches of the service at the expense of others, and also tend to secure a proper account for each and every department, whether its head is a good or a poor lobbyist or logroller, for grants of money to be utilized under his direction.

The facts reviewed lead the writer to his second statement of the fundamental provisions to be included in budgets of commissiongoverned cities, a budget arrangement with expenditures classified along functional lines easily understood by the people, with the further provision that these classified statements of proposed expenditures must be supported by similar statements of the expenditures of past years.

In the-classification of the expenditures of the budget, a complete separation should be made of the proposed authorized expenses or costs of governmental operation and maintenance, and outlays or expenditures for the more or less permanent properties, equipment, and improvements with a life in use of more than one year. This separation of proposed authorized expenses from outlays should not be confounded, as it too frequently is, with a special legal accounting for the proceeds of long term bond issues. The character of an expenditure is something quite different and apart from the sources or methods by which the money is obtained to meet the same, or the legal requirements for the proper accounting of such moneys. Both expenses and outlays may be financed by moneys obtained from revenues or from bond issues, and the amount from each class of expenditure which it is proposed by the budget to be financed from revenue and from bond sales should be separately and distinctly stated; otherwise the budget will not be a clear-cut statement of the relation of costs of government to methods of financing 
these costs; and without such statement, no sound judgment can be predicated upon the budget with reference to the outcome of the proposed financial transactions of the year.

In the foregoing pages the writer has briefly outlined the fundamental provisions that must be contained in the budgets of commission-governed cities, in order that such budgets may assist in securing popular control over municipal administration, and aid in maintaining economical, wise, and efficient government. Those provisions may be briefly summarized by saying that to accomplish the ends desired, budgets must be-

a. Complete exhibits of all proposed expenditures and of suggested methods of providing money to meet the same, as well as statements of the effect of such expenditures upon municipal indebtedness.

b. Statements of the relation of the current expenditures to broad and comprehensive plans for city building, and proposed schemes for financing those plans in future, and the relation of all these plans to present and future taxation and indebtedness.

c. Statements of expenditures classified in groups and subgroups and subordinate details, so arranged as to show the comparative wisdom of each and all, and the comparative merits of each. These statements should be supported with other statements to aid in forming correct judgments concerning the economy and efficiency of current administration.

But neither the municipal financial proposals, such as are usually found in budgets, nor the classifications described will suffice to accomplish the ends desired-the attainment of the most desirable administration of city affairs. They will not afford a city commission all the data needed for their guidance, since by them they cannot tell whether the budget itself is framed along intelligent lines. Further, if this information is not at the command of the commission, it cannot be imparted by them to the public. The budget to be framed along intelligent lines must be based upon a mass of information relating to governmental affairs, and that information must be placed at the disposal of the general public as well as utilized by the commission. The information needed for this purpose may be briefly summarized as follows:

I. Statements of the expenses of a series of prior years so classified according to function as to disclose the actual and relative 
cost of every governmental activity for those years, such statements being supplemented by statistics and other exhibits showing the relative economy and efficiency of every branch of the public service, comparing one branch with others, and, as far as practicable, comparing the costs and efficiency of the several departments with those of similar departments of other cities, and showing the amounts met from general and from trust and other special funds.

2. Statements of past outlays for the more permanent properties and public improvements of the city and of the approximate value of such properties, etc., or the cost of reproducing them in present condition. Such statements should be so arranged as to set forth the amounts expended during each of a series of years for every object of outlay, and the amounts of money obtained for meeting these outlays from bond issues and from general and trust or other special revenues.

3. Statements of the relation of net funded debt, which is gross funded debt less sinking fund assets, to the present value of the more permanent properties and public improvements ascertained and stated as described in (2). In the preparation of such statements as those last referred to, and in making the comparisons here mentioned, the greatest care should be exercised that sufficient allowance be made for depreciation, waste, loss, wear, and of obsolescence in the properties and improvements whose present values are estimated.

4. Statements of proposed expenditures for current expenses and for outlays, classified according to the functional activity for which asked. All proposals for such expenditures should be accompanied with exhibits based upon past experience, demonstrating that they are needed for securing efficient government under economical administration, and that one functional activity is not favored at the expense of others.

5. Statements for a-series of years of the current contributions from revenue to sinking funds and for other methods of amortizing fixed debts. These should set forth in no doubtful manner the evidence that the amounts so contributed are materially greater than the amounts of current depreciation, obsolescence, waste, and loss in value of the properties and improvements secured by the bond issues, amortized or in process of amortization.

6. Detailed statements of the amounts, estimated as realizable 
and the amounts actually realized or received during each of several years from the revenues of the city, and the amounts that were borrowed each year on long and short term obligations. Statements of estimated revenues and of revenue receipts should be classified by source of revenue and by amounts derived from or belonging to general and to trust and other special funds.

7. Estimates, based upon past experience, of the probabie receipts during the ensuing year from each and all of the revenues provided by general laws other than receipts from the general property tax. These estimates should be so arranged as to show the amounts that will be available for use of the general and of trust and other specified funds.

8. Statements of the expenses and outlays for the ensuing year that it is proposed to meet by special assessments. These statements should be accompanied with other statements of the property upon which the special assessments are to be levied.

9. Statements of all cash balances of prior years classified according to the requirements of state statutes, or municipal charter provisions as to their derivation from (a) general revenues; (b) special revenues; (c) trust fund revenues; and (d) receipts from long term bond sales, and further classified with reference to appropriation incumbrances and thus shown as available for future appropriations or previously appropriated; and if previously appropriated, the special conditions attending their appropriation.

Io. Statements of bonds authorized but not issued, and of the appropriation incumbrances upon the proceeds of authorized but unused loans.

II. The rate of tax levy to provide in connection with the receipts mentioned in (7) and (8) and the cash and other balances mentioned in (9) and ( 10 ) for meeting all the proposed expenses and outlays, and to contribute to debt amortization as mentioned in (4) and (5).

12. Exhibits showing all the facts relating to the borrowing power of the municipality, the amount of outstanding past loans and all loans authorized but not issued, and the other existing liabilities authorized or incurred that affect the borrowing power of the municipality. 